\begin{tabular}{l}
\hline 臨 \\
\hline
\end{tabular}

\title{
メニエール病症例の内リンパ囊手術の遠隔成績
}

（2）前庭所見及び前庭水管断層所見

深谷 卓*・小松崎 篤**・蜂屋 順一***
吉浜 博太****

\section{Long-term Results of Endolymphatic Sac Operation in Meniere's Disease}

\section{Part-2. Vestibular Findings and Diagnostic Significance of Vestibular Aqueduct Tomography}

Takashi Fukaya

(Tokyo University)

Atsushi Komatsuzaki

(Toho University)

\section{Jun-ichi Hachiya and Hirota Yoshihama}

(Kanto Teishin Hospital)

(1) The endolymphatic sac operation was performed on 28 ears with Meniere's disease. At the operations, the endolymphatic sac was drained in 16 ears (Drainage Group). In the other ears, simple mastoidectomy and uncovering of the posterior cranial fossa dura were conducted (Mastoidectomy Group).

The results were evaluated one year after the operations with respect to vertigo. Vertigo was successfully controlled in $82.9 \%$. No difference was found between the above two groups.

(2) The vestibular aqueduct was studied using temporal bone tomography. One hundred and eight ears with Meniere's disease served as subjects. The vestibular aqueduct was identified in $48.1 \%$ of the healthy ears, and $42.6 \%$ of the sick ears.

There was a correlation between the visibility of the vestibular aqueduct on tomography and the development of the endolymphatic sac.

$$
\text { はじめに }
$$

この報告はメニエール病症例に対する内リンパ囊手術の遠隔成績を論じたものである．既に第一 報1)において聴覚所見について報告しているが，その要旨は 1 ) 内リンパ囊手術後 3 力月程は聴力

\footnotetext{
*東京大学医学部耳鼻咽喉科学教室（主任：野村恭也教授）

**東邦大学医学部耳鼻咽喉科学教室（主任：小松崎篤教授）

***関東聥信病院放射線科

****関東聥信病院耳鼻咽喉科
} 
の変動が著しい．２）内リンパ囊への手術侵襲の程度にかかわらず，術後聴力は術前聴力の変動範 囲内に入り $(76 \%)$ ，また術後聴力は術前聴力の型や程度および内リンパ囊の発達程度とは相関を もたない，の 2 点である. 今回は術前・術後に各最低 1 年間観察しえた症例において，前庭所見の 変化を検討し, 併せて前庭水管の断層写真の有用性を考察し, 若干の知見を得たので報告する。

\section{対象と方法}

前庭所見の検討の対象は第一報と同一の症例 18例を含む 28 症例 28 耳である．全症例とも一側 性のメニエール病症例で, 男性19例, 女性 9 例 である。初診時年齢は22歳から57歳で, 平均 36 . 5 歳である. 平均罹患年数は 4.7 年である. 術 前聴力は表 1 に示す通りである.

この28例を大きく，内リンパ囊開放群16例と 内リンパ囊未発達群 12 例に 2 分した。前者は手 術時に内リンパ囊が確認され，その外側壁にメ スにて切開を加え, 内リンパ囊を乳突洞内へ開 放した症例群であり，後者は後半規管骨包より 後方では内リンパ囊を確認しえなかった症例群 である.

症例全体について，及び上記の 2 群間におい て, 術後のめまい発作の有無之程度・頻度につ いて検討した。

前庭水管の断層写真については, 喜多村らの 報告 ${ }^{2)}$ にある様に, Philips Polytome を用い， hypocycloid 軌道にて focus は0.6mm とし, 露出時間は 6 秒間で矢状面にて撮影を行なっ た。深度は外耳皮膚面より約 $38 \sim 40 \mathrm{~mm}$ の部位 を中心に $1 \mathrm{~mm}$ 間隔で撮影した。図 1 に示すよ うに common crus が認められる断層面で前 庭水管が観察される。

この前庭水管の断層写真を術前 - 術後長期観 察しえた前記の 28 症例と, その他 26 症例のメ二 エール病症例の計54症例 108 耳に施行した。 そ の他の 26 症例は患側・健側の比較のために全て

表 |内リンパ囊手術症例の術前聴力（28症例）

\begin{tabular}{c|c}
\hline$\sim 30 \mathrm{~dB}$ & 5 \\
\hline $31 \sim 60 \mathrm{~dB}$ & 20 \\
\hline $61 \mathrm{~dB} \sim$ & 3
\end{tabular}

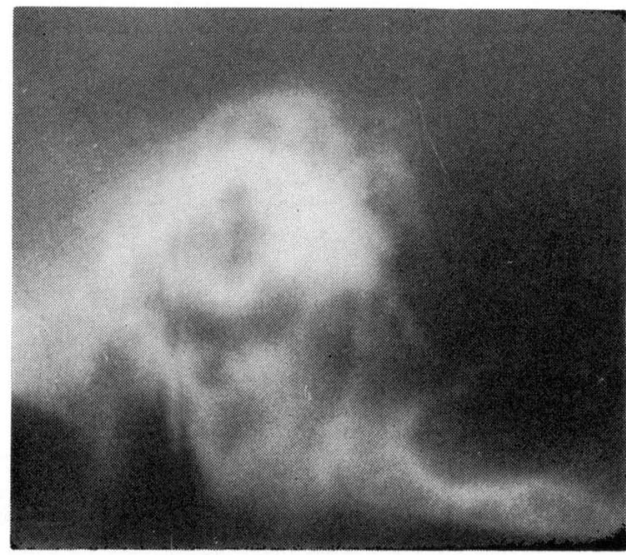

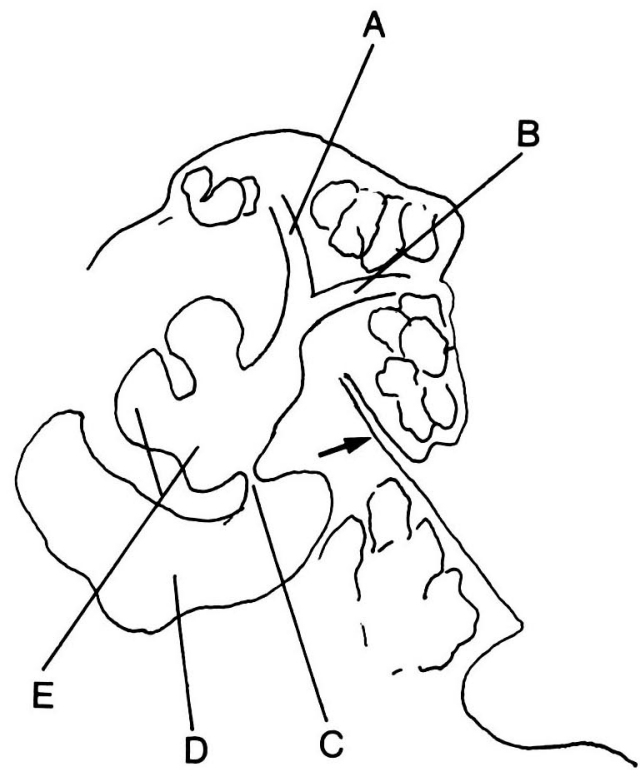

図 I 左側頭骨断風写真
A : 前半規管
B : 後半規管
C : 正円空
D : 鼓室
$\mathrm{E}:$ 蜦牛 
一側性のメニエール病症例を選び，男性17例， 女性 9 例で, 罹患耳は右側14例, 左側12例であ る. 初診時年齢は13歳から68歳の範囲であり, 平均は 42.7 歳である. 平均罹患年数は 3.8 年で ある。

前庭水管の断層写真については, 前庭水管の

結

術前・術後一年以上観察し，内リンパ囊手術 を行った症例では，術前はいずれの症例もめま い発作を頻回におこしている。罹患期間も平均

4. 7 年と長く, 難聴も中程度以上のことが多か った。術後のめまい発作は表 2 に示すように， めまいが消失したもの 12 例，回転性めまいが消 失し浮遊感に変化したもの 6 例, めまい発作が 散発的におこるもの 7 例, 全く変化なく発作が 続くもの 3 例となった。手術適応をめまい頻発 患者としたために，悪化例はなかった。少なく とも 1 年間の経過では，めまいが消失したもの は42.9\%で，めまいが改善したものは89.3\%で あった。

内リンパ囊手術の効果を内リンパ囊開放群之 内リンパ囊未発達群とに分けて検討すると, 表 3 に示すように両者の間に差を見出しがたい.

つまり内リンパ囊手術のめまいに対する効果は , 聴覚所見之同様に, 内リンパ囊への侵襲程度 とは関係しないととが分った。

前庭水管の断層写真については, 前庭水管の 内径や長さは測定せず，比較的観察しやすい屯 のも狭い前庭水管も観察可能なものは一括し た。その結果は表 4 に示すように，メニエール 病54症例中, 患側では23耳（42.6\%）で前庭水 管が観察され，健側では26耳（48.1\%）で前庭 水管が観察された，健側の方にやや前庭水管の 可視度が高いように見えるが有意差はない.

内リンパ囊手術を行った28症例について，断 層写真におりる前庭水管の可視 - 不可視之手術 時の内リンパ囊の発達度とを比較してみると表 5 に示すようになる。内リンパ囊手術を行った 28症例中, 12 症例で断層写真にて前庭水管が確
内径や長さは測定せず，同定度のみ検討した。 まずメニエール病罹患側と健康側での同定度の 差を見た。また内リンパ囊手術を行った28症例 では手術所見と前庭水管の同定度とを比較検討 した。

\section{果}

認され，16症例では前庭水管は同定しえなかっ た。内リンパ囊手術時に，断層写真にて前庭水 管が同定された12症例中11例にて内リンパ囊が 確認され，乳笑洞内へ開放するととが可能であ った。残のり 1 症例はで後半規管より後方では

表 2 めまいに対する内リンパ嚢手術の効果

\begin{tabular}{l|c} 
めまい消失 & 12 \\
浮遊感変化 & 6 \\
めまい減少 & 7 \\
不 変 & 3
\end{tabular}

表 3 内リンパ囊手術所見とめまいの予後の関係 (28症例)

\begin{tabular}{l|c|c}
\hline & $\begin{array}{c}\text { 内リンパ } \\
\text { 囊開放群 }\end{array}$ & $\begin{array}{c}\text { 内リンパ霊 } \\
\text { 未発達群 }\end{array}$ \\
\hline めまい消失 & 6 & 6 \\
浮遊感に変化 & 4 & 2 \\
めまい減少 & 4 & 3 \\
不変 & 2 & 1
\end{tabular}

表 4 前庭水管のレントゲン的同定 (メニエール病54症例)

\begin{tabular}{cc|c|c}
\hline & & 可 視 & 不可 視 \\
\hline 健 & 耳 & 26 & 28 \\
患 & 耳 & 23 & 31
\end{tabular}

表 5 前庭水管のレントゲン的同定と内リンパ箠手術 所見の関係

\begin{tabular}{lr|c|c}
\hline & & $\begin{array}{c}\text { 内リンパ } \\
\text { 囊開放群 }\end{array}$ & $\begin{array}{c}\text { 内リンパ霁 } \\
\text { 未発達群 }\end{array}$ \\
\hline 前庭水管 & 可視 & 11 & 1 \\
& 不可視 & 5 & 11
\end{tabular}


内リンパ囊は見出せなかった。逆に断層写真に て前庭水管が確認されなかった16症例では術中 に11症例で内リンパ囊が確認されず， 5 症例で 確認され乳突洞へ開放された。この結果より，

\section{考}

メニエール病の外科的治療は決して単一でな く, sense organ を対象とした超音波手術, 前庭神経を対象とした前庭神経切断術（経中頭 蓋窩，経後頭蓋窩)，内耳の血行を対象とした 交感神経切除術，迷路破壊術，そして内リンパ 囊手術がある。どの方法も得失があり決定的之 はいえない (Schuknecht ${ }^{3)}$ ).

内リンパ囊手術に関しても第一報1に述べた 様に多くの変法が存在する，我々の今回の報告 は Portmann 原法 ${ }^{4)}$ と乳哭洞削開・後頭蓋窩硬 膜開放術とを比較検討したものである。その結 果は前庭所見も恥覚所見同様に両群の間で差を 見出しがたい。乙の報告は外転法 ${ }^{5)}$ や House, Arenberg らの shunt ${ }^{6 / 7)}$ 法との比較は行なっ ていないが，Portmann 原法と乳突洞削開・後 頭蓋窩硬膜開放が予後の差がないととは重要な 知見之考える．何故なら，外転法にしろ， shunt tube 法にしても内リンパ囊の開放をより 持続的に保持することを目的とした変法である のに，単に後頭蓋窩硬膜を開放したのみで，内 リンパ囊に操作を加えずとも諸変法と同じ効果 を得られるからである。乙の点で我々は Shambaugh $^{15)} の$ decompession 手術之意見を同 じくする.

内リンパ囊手術は確立した手術のように考え

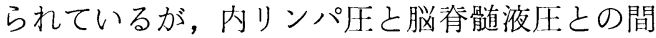
の圧差の存在, 前庭水管が狭く短い症例で内リ ンパ囊を開放することへの疑問や機能的にみて 内リンパ囊を切開してしまうことの適否など問 題の多い手術である。 また Portmannの報告8) にある様に長期間観察すると再発の多い手術で あある。内リンパ囊手術は，手術自身の可否を 含めて再検討の要があると思われる.

前庭水管をレントゲン的に同定する試みは19
前庭水管の断層写真による同定度は内リンパ囊 手術時の内リンパ囊の同定度，つまり内リンパ 囊の後頭蓋窩硬膜上への発達程度と強い相関関 係をもことが分った。

察

68年に Clemis と Valvassori ${ }^{9)}$ によって始め られた。その後 Arenberg ${ }^{10)}, W_{i l b r a n d}{ }^{11)}, \mathrm{Br}^{-}$ ünner ${ }^{12)}$ らが詳細な報告を行っている。 どの報 告でも正常人では $90 \%$ 以上に前庭水管が観察さ れる。またメニエール病では健側・患側とも前 庭水管のレントゲン的同定度は50\%程と低い。 健側耳之患側耳間の同定度の差は，Valvasso$\mathrm{ri}^{13)}$ の報告を除いて，認められていない。我々 の今回の報告ではメニエール病54症例中，患側 で $42.6 \%$ ，健側で $48.1 \%$ 亿前庭水管を認めてお り，健側・患側間での有意差は認めなかった。

メニエール病で前庭水管の同定度が両側性に 低いととが，メニエール病の病態と関係がある かが問題となってくる．前庭水管は小児期に乳 乫洞の発達と共に発育・延長する。坚期の乳 㔖洞発達を阻害する大きな原因は中耳炎であ る. 従って Øigaard ら ${ }^{14)}$ が報告した様に,メ ニエール病と同様に慢性中耳炎でも前庭水管の レントゲン的同定度は低い。つまり前庭水管の レントゲン的同定度が低いことはメニエール病 に特徴的な所見ではないことは明らかである。 しかし周知の如くメニエール病の中耳炎頻回罹 患例は稀である。そこでメニエール病には先天 的に前庭水管の発育を両側性に阻害する要因が あるという仮説が生じる。けれどあメニエール 病の両側罹患例は多い訳ではなく，また前庭水 管が狭く短いことが発症に関係あるのか否かも 問題として残る。

Arenberg ${ }^{10)}$ はメニエール病症例を前庭水管 がよく観察されるI 群，観察されないП群とに 分け，内リンパ囊手術の結果はI群では良好で あるが，【群では不良であると報告している。 今回の我々の報告では内リンパ囊開放群が I 群 に，内リンパ囊未発達群が П群とほぼ同義であ 
る。しかし内リンパ囊手術の結果は Arenberg の報告とことなり，両群間に予後の差異は認め られなかった。

前庭水管の断層写真は手術解剖を知る上で極 めて有用である．前庭水管が同定される症例で は内リンパ囊開放手術は容易で, 逆に同定され ない症例では内リンパ囊手術には困難が伴うと 推定される。
最後に我々は, 内リンパ囊手術は決して根治 的手術でなく，一時的に聴覚所見の悪化を止め ，めまいを軽減する手術だと考える。その理由 は開放した内リンパ囊が長期間にわたって結合 織で閉鎖されないという根拠はないからであ る. 従ってその適応は現在よりも早期の聴力損 夫の少ない時期であって良いと思われる.

\section{ま と め}

(1)28例の内リンパ囊手術症例の前庭所見変化を 1 年間観察した。全体の $89.3 \%$ めまいは軽減し た.内リンパ囊開放群(Portmann 原法)と内リンパ囊未発達群の間に予後の差異は認めなかった。

(2)メニエール病症例 54 例 108耳の前庭水管の断層写真を検討した。その結果，健側で $48.1 \%$ 亿, 患側で $42.6 \%$ 亿前庭水管を同定しえた。断層写真での前庭水管の同定度と，手術時の内リンパ囊の 発達度とは相関関係をむっていた。

野村恭也教授の御指導・御校閲に深謝いたします。

\section{参 考 文 献}

1) 深谷卓, 浅井昌大, 小松崎篤 : $x=エ ー ル$ 病症例 の内リンパ囔手術の遠隔成績. (1)聴覚所見, 耳鼻 臨床. $73: 1687 \sim 1692,1980$.

2) 喜多村健, 小松崎篤, 蜂屋順一, 吉浜博太 : $x=$ エール病症例における前庭水管のレントゲン学的 考察. 耳鼻臨床 $70: 1762 \sim 1770,1977$.

3 ) Schuknecht, H.F : Surgical Modalities. Arch. Otolaryngol. $97: 129 \sim 132,1973$.

4) Portmann, G. : The saccus endolymphaticus and an operation for draining the same for the relief of vertigo. J. Laryngol. Otol. 42 : 809 817, 1927.

5 ）北原正章：メニエール病に対する89例の内リンパ 囊手術経験 耳鼻臨床 $69: 1270 \sim 1277,1976$.

6) House, W. : Subarachnoid shunt for drainage of endolyhampttc hydrops. Laryngoscope 72 : 713 729, 1962.

7 ) Arenberg, K., et al : Endolymphatic sac valve implant surgery. Laryngoscope Suppl. 17 $1 \sim 15,1979$.

8 ) Portmann, M. : Decompression and drainage of the endo-lymphatic sac. Arch. Otolaryngol. $97: 125 \sim 128,1973$.

9) Clemis, J. D. and Valvassori, G. E. : Recent radiographic and clinical observations on the vestibular aqueduct. Otolaryngologic Clinics of North America 339 346, 1968.

10) Arenberg, $K_{\text {., et }}$ al : The surgical anatomy of the endolymphatic sac. Arch. Otolaryngol. : 103: $1 \sim 11,1977$.

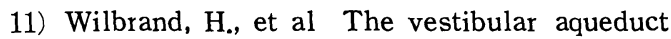
on the paravestibular canal. Acta Radiol. 15 337 355, 1974.

12) Brünner, S., and Pedersen, C. B. : Radiological evaluation of Meniere's diseae. ORL 21 : $1 \sim 8,1974$.

13) Valvassori, G.E. : Meniere's disease. Excerpta Medica International Congress Series 206 : 612 613, 1969.

14) Øigaard. A., e al : The vestibular aqueduct in Meniere's disease. Arch. Otolaryngol. $96: 553$ $\sim 555,1972$.

15) Shambaugh, G.E. : Surgery of the endolymphatic sac. Arch. Otolaryngol. $83: 305 \sim 315$, 1966.

$\left.\begin{array}{l}\text { 原稿到着: 昭和 } 56 \text { 年 } 1 \text { 月 } 19 \text { 日 } \\ \text { 別刷請求先: 深谷卓 } \\ \text { †11 } \\ \text { 東京都文京区本郷 } 7 \text { 丁目 } 3-1\end{array}\right)$

